\section{sciendo \\ ENVIRONMENT PROTECTION POLICY AND MONITORING SYSTEMS FOR POLYMETALLIC NODULES EXPLOITATION}

DOI 10.2478/ntpe-2018-0065

dr hab. inż. Tomasz Abramowski

Maritime University of Szczecin, Poland

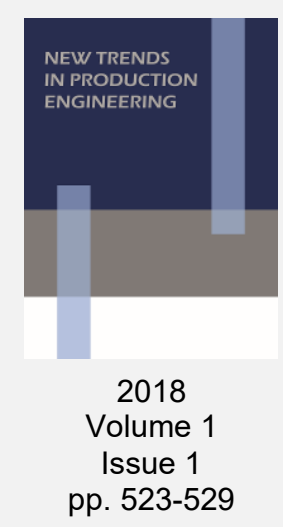

\begin{abstract}
The paper presents the analysis of ongoing implementation of environmental protection policies into deep seabed mining projects of Clarion-Clipperton Fracture Zone, (CCZ). Short introduction to the current environmental regime in the Area under UNCLOS jurisdiction is presented and potential impact of deep seabed mining is discussed. Selected results of efforts to minimize the impact on the marine environment and environmental baseline studies are described.
\end{abstract}

Keywords: deep sea mining, protection of environment and monitoring, polymetallic nodules

\title{
INTRODUCTION
}

Ocean mineral deposits have a potential to become an alternative source of metals and important for modern sustainable economies. In particular polymetallic nodules contain many of them with high concentrates of $\mathrm{Cu}, \mathrm{Ni}, \mathrm{Co}, \mathrm{Mn}, \mathrm{Mo}$ and such elements as $\mathrm{Pb}, \mathrm{Zn}, \mathrm{Pt}, \mathrm{Li}, \mathrm{Ag}, \mathrm{Y}$, REE that can be considered as by-products. Land base resources of the metals are being depleted during the last decades and usually land extracted ore contains lower grades of the metals than polymetallic nodules. The recent research indicates that deposits of polymetallic nodules and other marine minerals like cobalt-rich ferromanganese crusts and polymetallic massive sulphides have the potential to be economically feasible for mining in the presence of favorable metal prices on the world market.

Polymetallic nodules in particular promise to make a vast contribution to the world's resource base. It is estimated that polymetallic nodule deposit in the eastern equatorial Pacific (ClarionClipperton Zone, CCZ) have 1.1 times more Mn, 1.85 times more Ni, 3.2 times more Co than the entire world land-based reserves for the metals, (Morgan, 2000).

The deposit covers large seabed regions beyond national jurisdiction (the Area), and is managed by the International Seabed Authority (ISA) in accordance with the UN Convention on the Law of the Sea (UNCLOS). The ISA is responsible for administering the mineral resources of the Area, including such activities as: prospecting, exploration and exploitation activities related to the resources.

Potential for new opportunities result in a number of exploration activities carried out by both commercial and governmental entities. ISA has granted several exploration contracts. As at 31 May 2017, a total of 27 contracts for exploration had entered into force (17 for polymetallic nodules, 6 for polymetallic sulphides and 4 for cobalt-rich ferromanganese crusts). Some recommendations for institutional and system managing mining of the deep seabed are discussed in (Wedding at al., 2015).

The Interoceanmetal Joint Organization (IOM), an intergovernmental consortium certified by the governments of Bulgaria, Cuba, Czech Republic, Poland, Russian Federation, and Slovakia, signed a contract with the ISA for the exploration of polymetallic nodule deposits in the area $\left(75000 \mathrm{~km}^{2}\right)$ situated in the eastern part of the CCZ, NE Pacific on 29 March 2001. 


\section{CURRENT ENVIRONMENTAL REGIME IN THE AREA}

The responsibilities to protect marine environment in the Area have to be shared between all States parties to the UNCLOS as the Area while its resources are a common heritage of mankind. As a part of this policy, the ISA Council in 2012 adopted a preliminary environmental management plan for the Clarion-Clipperton Zone in the Eastern Central Pacific. The plan included the designation a system of Areas of Particular Environmental Interest (APEls), (Fig. 1). The APEls are excluded from the system of exploration based on exclusive rights for a contractor and will be the subject of environmental baseline monitoring and further observations.

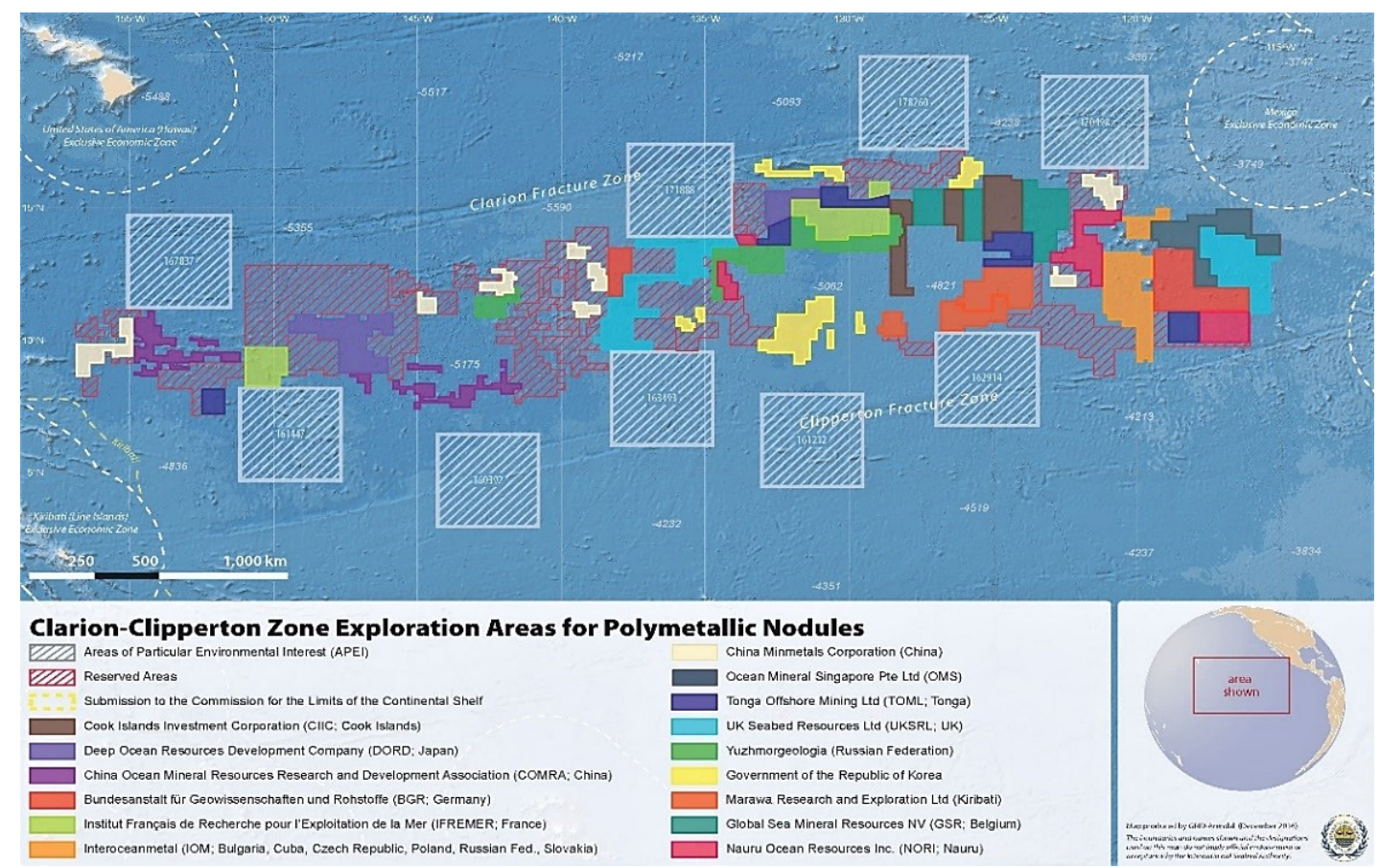

Fig. 1. Location of areas assigned to particular environmental interest (APEIs) and areas granted by the International Seabed Authority for the exploration of polymetallic nodules (contract areas), and in the Clarion-Clipperton Fracture Zone, NE Pacific.

Source: International Seabed Authority, www.isa.org.jm

The legal framework with respect to the development of environmentally responsible mining technologies currently includes the UNCLOS provisions, (International Seabed Authority, 2001):

a) The obligation for States parties to take necessary measures with respect to activities in the Area to ensure effective protection for the marine environment from harmful effects that may arise from such activities, to which end the Authority shall adopt appropriate rules, regulations and procedures (UNCLOS art. 145).

b) That measures taken by States to prevent, reduce and control pollution of the marine environment shall deal with all sources of pollution of the marine environment (art. 194 (3)).

c) The objective criteria that should be reflected in the rules, regulations and procedures to be adopted by the Authority with respect to the protection of the marine environment (annex III, article $17(2))$.

Moreover, the Agreement relating to the Implementation of Part XI of the UNCLOS, in particular section 1 of the annex thereto sets out several focus areas related to the protection and preservation of the marine environment that the ISA needs to concentrate on before approving the first plan of work for exploitation, (International Seabed Authority, 2017).

The ISA Council adopted as well the Regulations on Prospecting and Exploration for Polymetallic Nodules in the Area, which provide:

a) That the Authority and sponsoring States shall apply a precautionary approach as well as best environmental practices to ensure the effective protection of the marine environment. 
b) That the contractor is required to carry out impact assessments and environmental monitoring, in order to determine the effect of exploration activities on the marine environment. The contractor is also required to submit data and information to the Authority, upon expiration of the contract, regarding equipment used to carry out exploration work, including the results of tests conducted on proposed mining technologies. The Legal and Technical Commission of the ISA issued the recommendations for the guidance of contractors for the assessment of the possible impacts arising from exploration for marine minerals in the Area.

The above mentioned Regulations on Prospecting and Exploration also contain various provisions that refer to the technical capability and the technical qualifications of the applicant and/or contractor, as well as to the role of the Authority in assessing that capability. In addition, during the exploration phase, the contractor has the obligation to complete the necessary preparatory work before being able to proceed to the exploitation stage.

\section{ANTICIPATED IMPACTS OF DEEP-SEA MINING OF POLYMETALLIC NODULES}

Mining will include picking up the polymetallic nodules and separating them from the surrounding fine-grained sediments, lifting nodules to the ocean surface, separating them from the seawater and sediment entrained in the lift operation, and transporting them to the onshore metallurgical facility. Each of those operations poses environmental risks for seafloor, water column and sea surface that needs to be assessed, minimized and mitigated in any future mining project.

The nodules typically occur on the abyssal plains of ocean areas, with slow recovery. Although deposit fluxes of organic matter from the productive zone to the sea floor are very low, the layer of sediment at the abyssal plains can be thousands of meters deep. The top layer is porous, therefore very loose, and easily disturbed. Food levels are limited; the biomass of the sedimentinhabiting fauna is low. However, biodiversity can be considered high, with some species probably widely distributed and others restricted to single locations only

Picking up the nodules and removing the associated fine-grained sediments fundamentally will disturb the benthic habitat in the mining area and will generate sediment plumes near the seafloor which be transported by the bottom currents at some distance away from the mining tracks. Nodule-lifting operations will include the entrainment of significant volumes of deepocean seawater, associated biota and sediments that require their discharge after the separation of nodules on board of mining ship.

The essentially permanent removal of nodules within the mining collector track will directly destroy the hard substrate upon which the nodule epi- and in-fauna depend, thus a significant portion of bottom dwelling animal communities will be endangered, (Morgan et. al, 1999, Oebius et. al, 2001, Thiel ed., 2001). Because abyssal nodule habitats normally are very stable (possibly the most physically stable habitats on Earth) and are dominated by very small and/or fragile animals, the direct effects of commercial-scale nodule collection are predicted to be devastating to the benthos. In addition, the sediment dwelling organisms inhabiting the upper few centimeters of bottom sediments between and beneath the nodules will be also damaged by redeposition and penetration deeper into the sediments.

The potential impact of nodule mining on the benthic environment was investigated during a number of experiments as DOMES, DISCOL, BIEs, JET, and INDEX and more essential environmental issues were identified, e.g.: (Lavelle et. al, 1981, Ozturgut et al. 1981, Radziejewska et. al, 2001, Trueblood et al., 1997, Yamada and Yamazaki, 1998, Sharma, 2011). Although these experiments produced disturbances much lower in intensity and many orders of magnitude smaller in spatial scale than would result from commercial mining operations, they provide some insights into the sensitivity and recovery times of abyssal nodule communities subjected to mining disturbance. Some of these studies have been shown not to have any deleterious effects or have been demonstrated to have minor or otherwise acceptable impacts without the danger of producing serious long-term, wide-ranging, and undesirable consequences. 


\section{INTEROCEANMETAL EFFORTS TO MINIMIZE THE ANTICIPATED IMPACT ON THE MARINE ENVIRONMENT}

The main objective of the IOM activity as a contractor with the ISA is to delineate nodule blocks and identify nodule resources/reserves within prime areas that could be mined in the future. In order to minimize the anticipated environmental impact from deep-sea mining of polymetallic nodules, the current efforts of IOM are also focused on a research of an optimal technology pattern in relation to the local geological, geotechnical and environmental baseline conditions of the area identified as the IOM's first generation mineable exploration block H11, (Stoyanova, 2013). For the development of such site-specific mining design, the following factors and criteria were considered: size of a mineable site, nodule grade and abundance, annual recovery rate for a single mining unit, duration of mining operations, dredge and sweep efficiency of the collector, seafloor disturbance etc.

The factors influencing the mining site determination include:

- production factors (annual recovery rate and duration of mining operations), which determine the cumulative nodule recovery required from a mine-site;

- site factors (nodule abundance and mineable ratio), which combine to indicate the tonnage of nodules available for recovery from mine-site;

- system and other factors (dredge and sweep efficiency, net nodule recovery, net mining efficiency etc.), which will determine the percentage of the available nodules that might actually be recovered.

Based on the available published information, a mining site was defined as a portion of the seabed, where a commercial operation could be maintained during 20-30 years with a production of 1.5 to 4 million tonnes per years of nodules with an average containing of 1.25$1.5 \%$ nickel, $1-1.4 \%$ copper, $27-30 \%$ manganese, and 0.2-0.25\% cobalt, (Herrouin et al. 1989, Sharma, 2011).

The IOM's site most perspective for future mining and having about $5370 \mathrm{~km}^{2}$ was selected on the base of comprehensive exploration research carried out within 2001-2009. Polymetallic nodules in the studied area are partially embedded in the semi-liquid layer (Fig. 2, middle) covering the seafloor up to $61 \%$ (Fig. 2, left), and the abundances amounted from 3.9 to 19.1 $\mathrm{kg} / \mathrm{m}^{2}$, averaging $13.4 \mathrm{~kg} / \mathrm{m}^{2}$ (wet nodules). At most studied stations $(78.4 \%$ ), the nodule abundance is higher than $10 \mathrm{~kg} / \mathrm{m}^{2}$, thus the local heterogeneity of habitat within the studied area comprises patchiness of nodule-bearing and nodule-free sites. Nodule size distribution can be summarised as follows: nodules < $2 \mathrm{~cm}: 4.0 \%$; $2-4 \mathrm{~cm}: 25.6 \%$; $4-6 \mathrm{~cm}: 30.3 \%$; $6-8 \mathrm{~cm}: 20.9 \%$; $>8 \mathrm{~cm}: 19.2 \%$, (Stoyanova, 2013).
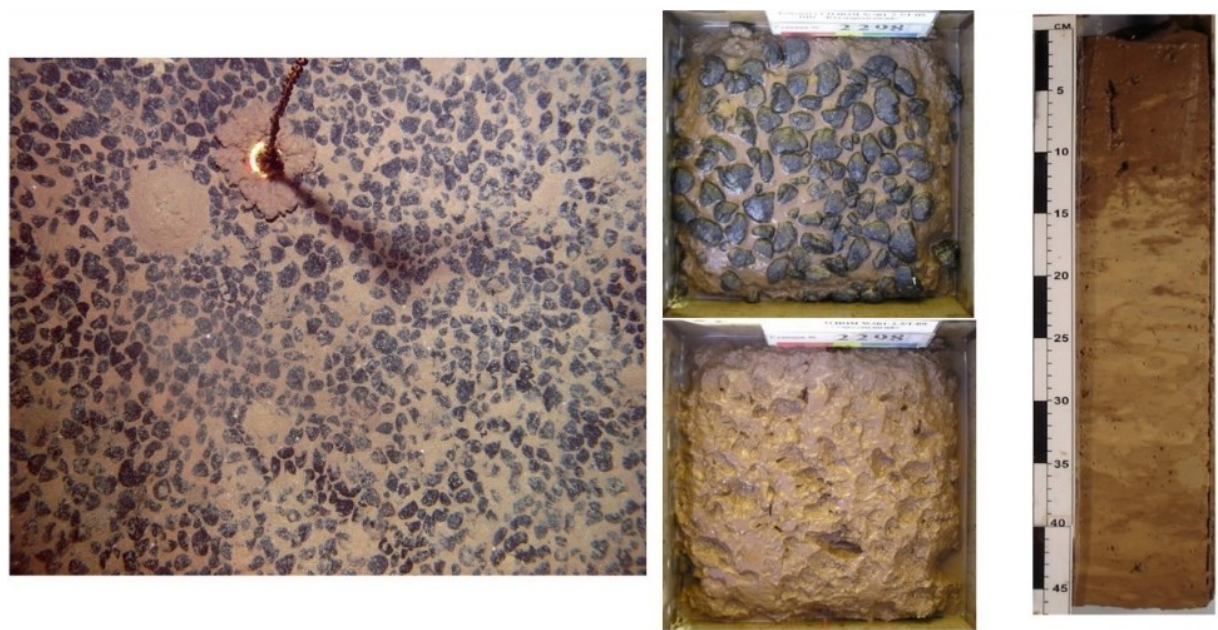

Fig. 2. Photograph of the seafloor (left) taken at the station with $59 \%$ estimated nodule coverage; on board box corer content photograph (middle, upper) with $16.6 \mathrm{~kg} / \mathrm{m}^{2}$ nodule abundance; on board box corer after collecting the nodules (middle, lower), and sediment core (right).

Source: Interoceanmetal expedition materials, with permission 
Sediments of the boundary semi-liquid layer (up to $15 \mathrm{~cm}$ thick) consist of siliceous ooze and siliceous-clayed ooze, the clay fraction accounting for $55.9-93.6 \%$ (85\% on the average) of the bulk weight. Sediment in the layers deeper than $15 \mathrm{~cm}$ was denser and more compact, clayey, and mottled due to the presence of remains of in faunal burrows filled with diagenetically transformed, darker material derived from the overlying sediment (Fig 2, right).

For the purpose of this study, taking into account current mining, geological and economic criteria and practices of nodule deposit contouring, a significant portion of about $1570 \mathrm{~km}^{2}(29 \%)$ was excluded from the previously recognized mineable site of $5370 \mathrm{~km}^{2}$. This exclusion was done due to the occurrence of topographic obstacles for the movement of nodule collector, metal-poor deposits with a total value of $\mathrm{Co}+\mathrm{Ni}+\mathrm{Cu}<2 \%$, and nodule deposits with less than $700 \mathrm{~m}$ in width. It was estimated that the size of the IOM's first generation minable site/block is about $3800 \mathrm{~km}^{2}$, virtually uniformly covered by nodules with their average abundance of 12.6 $\mathrm{kg} / \mathrm{m}^{2}$. A total resource of 48.1 million tonnes of wet nodules (or 33.9 million tonnes dry nodules) based on the kriging geostatistical method were estimated within the $\mathrm{H} 11$ mineable block, The anticipated environmental impact depends on the mining technology to be used. The recent concepts of mining system models are principally based on the Lockheed/OMCO mining system tested in the Pacific Ocean in 1976 and 1978 (Chung, 1985, Chung, 2003, Welling, 1981). In general, the integrated mining system includes the seafloor nodule collector, the buffer, pipe system for vertical transport, and the mining ship/platform (Fig. 3).

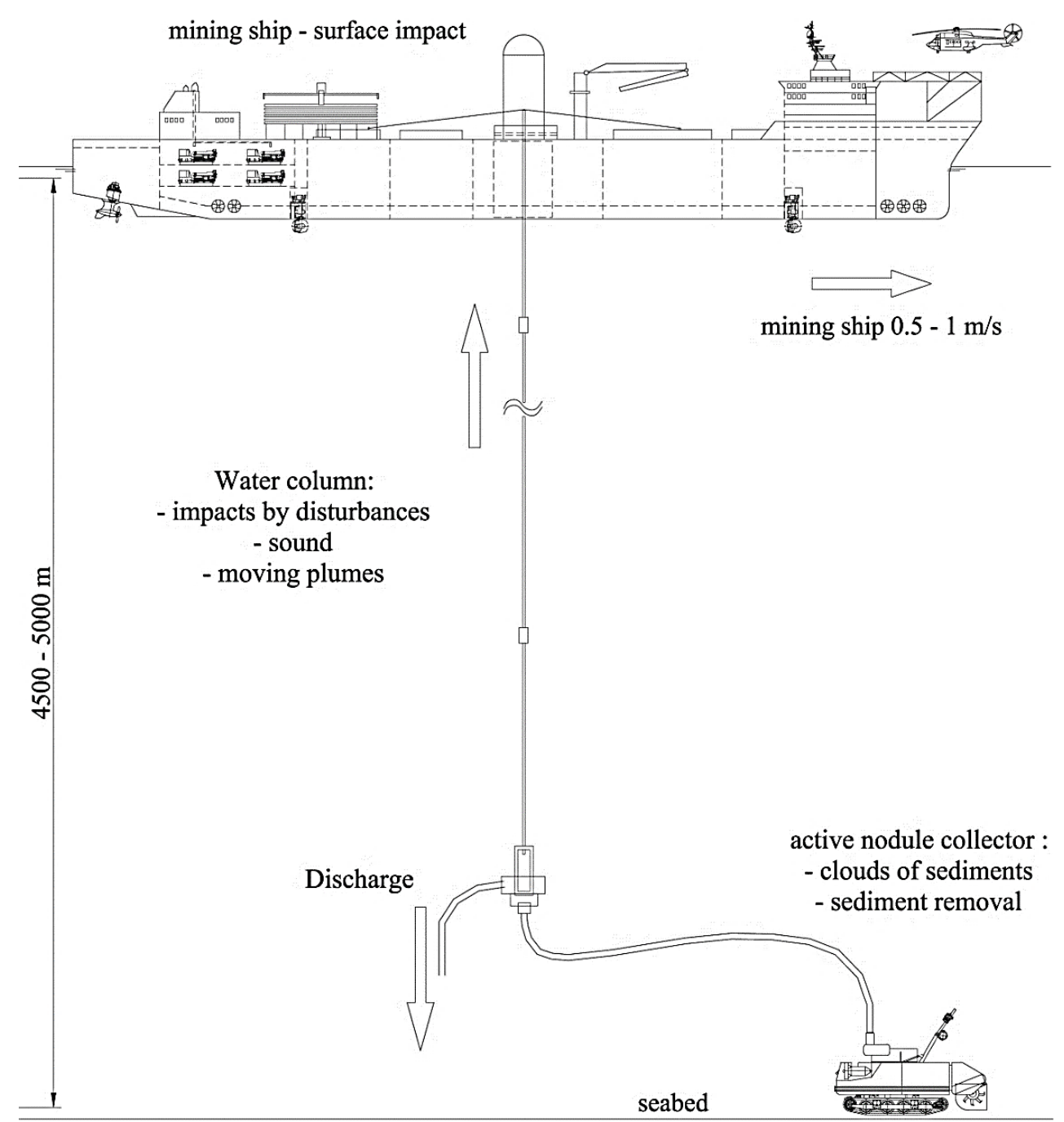

Fig. 3. General layout of the mining system with environmental impacts. Source: Interoceanmetal Joint Organization, with permission.

At the rate of 3 million tonnes per annum (dry nodules), with an annual operation time of 300 days/year for average nodule abundance of $12.6 \mathrm{~kg} / \mathrm{m}^{2}$, the relevant area of $0.79 \mathrm{~km}^{2}$ will be 
mined daily. Taking into account the mining system factors, i.e. both dredge and sweep efficiencies of 0.65 , it is assumed that an area of $0.52 \mathrm{~km}^{2}$ will be contacted daily by the nodule collector. Similar data were reported in (Ozturgut et. al, 1981, Sharma, 2011) where for commercial production of 10,000 and 5,000 t/day for an optimum nodule abundance of $10 \mathrm{~kg} / \mathrm{m}^{2}$, the actual area mined will be 1 and $0.5 \mathrm{~km}^{2} /$ day, respectively. In consequence, over 10 years' life of mining in the IOM's prime mineable block the seafloor area of $1548 \mathrm{~km}^{2}$ would be directly impacted by the mining operation, (Stoyanova, 2016).

At present, the IOM carries out the research and design works focused on a so-called hydraulic mining method. There are several proposals for the technical approach to be used in order to achieve satisfactory results in the operation of picking up the polymetallic nodules and transporting them vertically to the mining ship or platform.

To avoid the generation of a surface plume, the second discharge pipe supported by on-board pumps should be used to return the bottom water and remains of sediment particulates as well as dissolved nutrients and trace metals to the buffer subsystem after on-board separation of nodule fragments. The aim is to ensure that no mining impact should occur not only at surface water layer but also in the entire water column. The only impact to surface water will be the presence of the mining ship, the specialized bulk cargo carrier, and the riser and discharge pipes. Therefore, the bulk of seafloor re-suspended sediment, cut-off nodule fragments and the remains of benthic biota will be stored up in the buffer subsystem and periodically discharged in the path of the collector. It is assumed that the sediment blanketing will occur mostly within the already mining affected habitats and thus will ensure the survival of animals living outside the mining tracks.

\section{CONCLUSIONS}

The UNCLOS provides the set of rules for the effective environment protection from harmful effects, which may arise from the exploration activities of contractors in the Area, beyond the national jurisdiction. Basing on the accepted precautionary principles, the Environmental management plan was set up for the CCZ. The areas selected for particular environmental interest were delineated to safeguard biodiversity and ecosystem function in the abyssal Pacific region targeted for nodule mining.

Nevertheless, the commercialization of deep-sea nodule resources requires large-scale mining tests with subsequent monitoring programs that will yield results to allow the establishment of a reliable environmental impact assessment. The scale and subsequent impacts of mining operations on the environment are dependent on the mining technology used. At present, the exact technology to be used for the mining of polymetallic sulfides is not known, except for general assumptions and layouts. There is an urgent need to define the optimal technological pattern and environmentally friendly mining system design requirements in relation to the local geological, geotechnical and environmental conditions of the mineable area, already at the phase of early design guidelines, (Chung, 1985, Chung, 2003).

\section{REFERENCES}

Abramowski T., and Stoyanova V. (2012). Deep-sea polymetallic nodules: renewed interest as resources for environmentally sustainable development, Proc. $12^{\text {th }}$ Int. Multidisc. Sc. GeoConf SGEM, pp. 515-521.

Chung J.S. (2003). Deep-ocean mining technology: learning curve I, Proc. $5^{\text {th }}$ ISOPE Ocean Mining Symp., Japan, pp. 171-175.

Chung J.S. (1985). Advances in the manganese nodule mining technology, J Marine Technology, MTS, 19, 4, pp. 39-44.

Herrouin G., Lenoble J.P., Charles C. (1989). A manganese nodule industrial venture would be profitable. Summary of a 4 year study in France. OTC 5997, pp. 321-331.

International Seabed Authority: Development of environmentally responsible mining technologies: towards an approval process for mining equipment, submitted by the delegation of the Netherlands, (2017). ISBA/23/C/5, available at: www.isa.org.jm [Accessed 13 March 2018]

International Seabed Authority: The Law of the Sea, Comp. of Basic Documents, (2001). 
Lavelle J.W., Ozturgut E., Swift S.A., and Erickson B.H. (1981). Dispersal and resedimentation of the benthic plume from deep-sea mining operations, Mar. Mining, pp. 59-93.

Morgan C.L. (2000). Resource estimates of the Clarion-Clipperton manganese nodule deposits. In: Cronan D.S. e.d. Handbook of Marine Mineral Deposits, CRC Press Mar Science Series, Boca Raton, USA, pp. 145-170.

Morgan, C.L., Odunton N., and Jones A.T., (1999). Synthesis of environmental impacts of deep seabed mining, Marine Georesources \& Geotechnology, vol. 17, issue 4, pp. 307-356.

Oebius H.U., Becker H.J., Rolinski S., Jankowski J.A. (2001). Parameterization and evaluation of marine environmental impacts produced by deep-sea manganese nodule mining, DeepSea Res II (48), pp. 3453-3467.

Ozturgut E., Lavelle J.W., Erickson B.H. (1981). Estimated discharge characteristics of a commercial nodule mining operation, Mar. Mining, 3, pp. 1-17.

Radziejewska T., Rolicka-Praxmajer J., and Stoyanova V. (2001). IOM BIE revisited: Meiobenthos of the IOM BIE site 5 years after the experimental disturbance. Proc. $4^{\text {th }}$ ISOPE Ocean Mining Symp., Szczecin, Poland, pp. 63-68.

Sharma R. (2011). Deep-sea mining: economic, technical, technological, and environmental considerations for sustainable development, Marine Technology Society Journal, 45(5), pp. 28-41.

Stoyanova V. (2013). Baselines data support for developing of environmentally sound nodule mining systems, Proc. 10th ISOPE Ocean Mining Symp., Szczecin, Poland, pp. 18-21.

Stoyanova V. (2016). Protection of Marie Environment and Monitoring Systems for Deep Sea Mining, In. T. Abramowski, ed., Deep Sea Mining Value Chain: Organization, Technology and Development, Interoceanmetal Joint Organization.

Thiel H (Ed.) (2001). Environmental impact study for mining of polymetallic nodules from the deep sea. Deep-Sea Res II, (48), pp. 3427-3882.

Tkatchenko G.G., Radziejewska T., Stoyanova V., Modlitba I., Parizek A. (1996). Benthic Impact experiment in the IOM pioneer area: Testing for effects of deep seabed disturbance. In: Proc. of Int. Seminar on Deep seabed mining technology, Beijing, China, pp. C55-68.

Trueblood D.D., Ozturgut E., Pilipchuk M., and Gloumov I.F. (1997). The ecological impacts of the Joint U.S.-Russian benthic impact experiment, Proc. $2^{\text {nd }}$ ISOPE Ocean Mining Symp., Seoul, Korea, pp. 139-145.

Wedding L.M., Reiter S.M., Smith C.R., Gjerde K.M., Kittinger J.N., Friedlander A.M., Gaines S.D., Clark M.R., Thurnherr A.M., Hardy S.M., Crowder L.B. (2015). Managing mining of the deep seabed, Science, 349 (6244), pp. 144-145.

Welling, C.G. (1981). An advanced design deep sea mining system. Proc. Offshore Technology Conf., Houston, Texas, pp 247-250.

Yamada H., Yamazaki T. (1998). Japan's ocean test of the nodule mining system, Proc. $8^{\text {th }}$ ISOPE Conf., Montreal, Canada, pp. 13-19. 